\title{
Effects of an environmentally relevant concentration of diuron on oyster genitors during gametogenesis: responses of early molecular and cellular markers and physiological impacts
}

\author{
Akcha Farida ${ }^{1,}$ *, Barranger Audrey ${ }^{1}$, Bachere Evelyne ${ }^{2}$, Berthelin C. Heude ${ }^{3}$, Piquemal D. ${ }^{4}$, \\ Alonso P. 2, Sallan R. Rondon 2, Dimastrogiovanni G. 5, Porte C. 5, Menard Dominique 1 , \\ Szczybelski A. ${ }^{1}$, Benabdelmouna Abdellah ${ }^{6}$, Auffret M. ${ }^{7}$, Rouxel Julien ${ }^{1}$, Burgeot Thierry ${ }^{1}$
}

1 IFREMER, Lab Ecotoxicol, Rue lle Yeu,BP21105, F-44311 Nantes 03, France.

2 Univ Montpellier, Interact Host Pathogen Environm, UMR 5244, Ifremer,UPVD,CNRS, CC 80, F-34095

Montpellier, France.

3 Univ Paris 06, Univ Paris 04, Unite Biol Organismes \& Ecosyst Aquat BOREA,CNRS, Univ Caen

Normandie,Museum Natl Hist Nat,UMR 7208, 57 Rue Cuvier, F-75005 Paris, France.

${ }^{4}$ Acobiom, Cap Delta Biopole Euromed 2, 1682 Rue Valsiere,CS 77394, F-34184 Montpellier 04,

France.

5 IDAEA CSIC, Dept Environm Chem, Barcelona 1808034, Spain.

6 IFREMER, Lab Genet \& Pathol, Rue Mus Loup, F-17390 La Tremblade, France.

7 UBO CNRS IRD IFREMER, Inst Univ Europeen Mer, Lab Sci Environm Marin LEMAR, Rue Dumont Urville, F-29280 Plouzane, France.

* Corresponding author : Farida Akcha, email address : fakcha@ifremer.fr

\begin{abstract}
:
Genitors of the Pacific oyster Crassostrea gigas were submitted during gametogenesis to a short pulse exposure to the herbicide diuron at a realistic environmental concentration. Histological analysis showed no effect of diuron on gametogenesis course, sex ratio and reproductive effort. A non-significant increase in testosterone and progesterone levels was observed in genitors exposed to the herbicide. At cell level, diuron exposure was shown to modulate the phagocytic activity of circulating hemocytes. The results of a transcriptional analysis showed that diuron affected the expression of genes belonging to functions known to play a major role during oyster gametogenesis such as gene transcription regulation, DNA replication and repair, DNA methylation and cytokinesis. Taking into account the results we previously obtained on the same genitors, this study showed a negative effect of diuron on oyster reproduction by inducing both structural and functional modifications of the DNA.
\end{abstract}

Keywords : Oyster, Pesticide, Reproduction, Histology, Gene expression, RT-qPCR, Steroid, Immunity 


\section{INTRODUCTION}

Marine organisms living in coastal ecosystems are exposed to a variety of chemical compounds from anthropogenic origins related to agricultural or industrial activities that may impact and weaken the populations. Since the last decades, mass mortalities are regularly observed worldwide among marine invertebrates (Harvell et al. 1999), including the Pacific oyster Crassostrea gigas, a mollusk species living in intertidal zones and subjected to aquaculture production. Oyster farming industries are suffering from recurrent oyster mortality outbreaks with heavy socio-economical consequences on their activity. Oyster mortality is thought to be explained by complex interactions between oysters (its genetics and physiological status), microorganisms including potential pathogens, and the environmental parameters such as temperature (Samain et al. 2007; Schmitt et al. 2012; Petton et al. 2013). In Europe, pluridisciplinary research projects were conducted on this issue on both Marennes Oleron Basin in France (MOREST project) and Erbro River Basin in Spain (SCARCE and CEMAGUA projects) (Samain et al. 2007). Among findings, oysters were shown to be particularly vulnerable to physiological and environmental stressors during gametogenesis, when energy is particularly allocated to reproduction. Besides, water quality appears to be a critical point. The presence of chemical pollutants such as pesticides is particularly investigated for the risk it may represent for oyster health. Among pesticides, herbicides are frequently detected in oyster production basin, reaching coastal waters from exoreic catchment area with agricultural activities (Munaron 2004; Soletchnik et al. 2005; Buisson et al. 2008; Burgeot et al. 2008; Caquet et al. 2013). There is therefore a need for a more efficient assessment of the environmental risks associated with the presence of pesticides, which represent 20 out of the 45 dangerous substances identified by the European Water Framework Directive (2013/39/UE). Among substances, diuron (3-[3,4-dichlorophenyl]-1,1-dimethylurea) is a substituted urea compound registered as a pre- and post-emergent herbicide selective for broadleaf weeds and some annual grasses. Despite restriction of its use in France since 2008 (JO no. 204 September 4, 2007), diuron is still detected at high concentrations in coastal waters (Munaron et al. 2012; Buisson et al. 2008; Caquet et al. 2013) due to its fairly persistence in aquatic systems (Thomas et al. 2002). Moreover, diuron has already been reported as having diverse toxic effects on oysters, including genotoxicity in somatic and gamete cells (Bouilly et al. 2007; Akcha et al. 2012; Mai et al. 2013), embryotoxicity (Akcha et al. 2012; Mai et al. 2013) and immunotoxicity (Gagnaire et al. 2006, 2007; Luna-Acosta et al. 2012). As a consequence, diuron is a valuable substance to consider for analyzing the impact of herbicides on marine organisms. Despite an increasing interest on the subject over the last years, there is still a need to determine the toxicity of pesticides under environmentally realistic scenarios of exposure, considering potential transgenerational effects.

In this attempt, a recent study has been undertaken by exposing C. gigas oyster genitors to diuron during gametogenesis and investigating the toxic effects in both adults and their offspring. Thus, we have already demonstrated a genotoxic trans-generational effect of diuron by detecting primary DNA damage in both somatic, germinal, and reproductive cells of oyster genitors as well as chromosomal abnormalities in the offspring (DNA aneuploidy) (Barranger et al. 2014, 2015). Moreover, DNA damages were concomitantly observed with a reduced growth and also with developmental abnormalities in larvae from diuron-exposed genitors.

In the present paper, we analyzed the molecular and biochemical effects of diuron on C. gigas genitors by measuring the expression of genes relevant to key functions suspected to be affected by pesticide 
exposure, the levels of selected enzymatic activities and the activity of immune cell by flow cytometry. Besides, the impact of diuron exposure was also assessed on oyster reproduction process by both qualitative and quantitative histology and steroid quantification in gonads.

\section{MATERIAL AND METHODS}

\section{Chemical reagents}

Diuron (3-(3,4-dichlorophenyl)-1,1 dimethylurea, CAS number 330-54-1, Pestanal, analytical standard), acetonitrile (anhydrous, $99.8 \%$ ), 1-chloro-2,4-dinitrobenzene (CDNB), disodium salt of reduced form of nicotinamide adenine dinucleotide phosphate (NADPH), ultrapure reduced glutathione (GSH), hydrogen peroxide, imidazole, glutamine, and hydroxylamine were purchased from Sigma Aldrich Chemicals (France). Formaldehyde $35 \%$, glacial acetic acid, and butanol $100 \%$ were purchased from Carlo Erba (France), glycerin $86 \%$ was purchased from Roth (France), ethanol $95 \%$ was purchased from VWR, and paraffin (paraplast ${ }^{\circledR}$ ) was purchased from Leica (France). Trizol Reagent and DNAse I were purchased from Invitrogen, M-MuLV Reverse Transcriptase was purchased from BioLabs, and Syber Green Mix was purchased from Roche. Ultrapure deionized water was prepared using a Milli-Q system (Millipore, Molsheim, France). All other reagents were of analytical grade.

\section{Genitor origin and oyster husbandry}

As already mentioned in Barranger et al. (2014), the adult oysters were originated from wild genitors collected in the Marennes-Oléron Bay (France). Before the experiment, they were transferred from the field to the hatchery for a 1-month acclimatization period. Seawater was pumped directly from the Seudre river Estuary, filtered through a sand filter $(40 \mu \mathrm{m})$, and passed through UV rays before draining the tanks in a continuous flow system (output: $55 \mathrm{~L} \mathrm{~h}^{-1}$ ). Oysters were fed daily with a mixture of four marine microalgae, and the water temperature was maintained at $8{ }^{\circ} \mathrm{C}\left( \pm 1{ }^{\circ} \mathrm{C}\right)$ throughout the acclimatization period. In order to initiate the gonad maturation process, the temperature was then raised by $2^{\circ}$ per day for 1 week, to reach $19.8^{\circ} \mathrm{C}\left( \pm 0.3^{\circ} \mathrm{C}\right)$ at the start of the experiment.

\section{Diuron exposure during gametogenesis}

Once gametogenesis had begun (T0), the oysters were divided into three experimental groups (three 250-L tanks of 240 oysters each per group): a seawater control (SWC), a solvent control (SC, acetonitrile at $0.005 \%$ ), and a diuron-exposed (D) group. Two 7-day exposure periods took place at the start and mid-course of gametogenesis. The oysters were maintained in a closed circulation system throughout the exposure period. The seawater was changed every morning, and diuron and acetonitrile were added every day after seawater renewal to reach target concentrations in the tanks. The temperature was kept stable at $20^{\circ} \mathrm{C}$, and oysters were fed the same way as during the acclimatization period. During this experiment, the use of polar organic chemical integrative samplers (POCIS) in control and assay tanks allowed the measurement of both the background level of seawater contamination by pesticides and the reached diuron concentrations. POCIS data demonstrated that oysters were finally exposed to environmentally realistic concentrations of diuron: the concentration reached during the first (Tfp1, 48 
h after T0) and second (Tfp2, 5 weeks after T0) herbicide pulse was respectively of 0.2 and $0.3 \mu \mathrm{g} \mathrm{L}^{-1}$ (Barranger et al. 2014). The background contamination of the water used at the hatchery appeared low considering the few data available on the detection of pesticides in coastal water. In the case of diuron, its background concentration was nearly one order of magnitude lower than the one tested in our study.

At Tfp2, oysters from each group were then grown in normal conditions for an additional period of 3 weeks in order to reach maturity (Tp, 9 weeks after T0).

\section{Follow-up of gametogenic cycle and reproductive effort by qualitative and quantitative histology}

In order to determine both the sex ratio and gametogenesis stage, 30 oysters were sampled at the beginning and at the end of the experiment (Tp), in each experimental group, just before the onset of spawning. For each sampled individual, transverse sections were realized and fixed for histology in Davidson fluid (glycerin $10 \%$, formaldehyde $20 \%$, ethanol $95^{\circ} 30 \%$, sterile sea water $30 \%$, acetic acid $10 \%)$. The tissue samples were dehydrated in serial dilutions of ethanol, transferred in butanol, and embedded in paraffin wax. For each sample, 4- $\mu \mathrm{m}$ slides were prepared and stained according to the Prenant-Gabe trichrome protocol (Gabe 1968). The determination of sex and gametogenesis stage was based on microscopic observation (Nikon Eclipse 80i coupled to a Nikon DXM1200-C camera). Gonad and storage tissue conditions were graded respectively according to Heude Berthelin et al. (2001) and Berthelin et al. (2000). Briefly, gametogenesis stage 0 corresponds to the sexual resting stage. Stage I is defined as the early developmental stage (gonial mitosis) and stage II corresponds to the germinal lineage development. Stage III is characterized as the ripe gonad. Storage tissue development was graded as follows: growing at stage $\mathrm{A}$, dense and structured at stage $\mathrm{B}$, in regression at stage $\mathrm{C}$, and almost completely depleted at stage D.

The reproductive effort was measured at the end of the experiment (Tp) by using 15 slides of the 30 sampled oysters. Slides were scanned with a Nikon Super Coolscan 8000 ED slide scanner provided with a special medical slide holder (FH-8G1, Nikon). The resolution used was 4000 dots per inch (dpi). Total section and gonad surfaces were measured using Vision assistant software. Gonadal index was calculated as the ratio of gonad area over total section area (Royer et al. 2008).

\section{Titration of total steroid levels in oyster gonad}

Progesterone (P4), testosterone (T), and estradiol (E2) were measured as described in Dimastrogiovanni et al. (2015). Briefly, gonad samples (0.2-0.5 g wet weight) were homogenized in 2 $\mathrm{ml}$ ethanol and frozen overnight at $-80^{\circ} \mathrm{C}$. Homogenates were then extracted with $2 \mathrm{~mL}$ of ethyl acetate $(\times 3)$; the organic extract was evaporated under nitrogen, resuspended in $1 \mathrm{~mL}$ methanol containing $1 \%$ $\mathrm{KOH}$, and incubated at $45^{\circ} \mathrm{C}$ for $3 \mathrm{~h}$. After the saponification step, Milli-Q water (4 ml) was added and the sample extracted with dichloromethane $(3 \times 3 \mathrm{~mL})$. The efficiency of the extraction procedure was $65.4 \pm 1.3 \%$ for $\mathrm{T}, 62.4 \pm 0.8 \%$ for E2, and $52 \pm 3.8 \%$ for P 4 .

Dry extracts were resuspended in $50 \mathrm{mM}$ potassium phosphate buffer $\mathrm{pH} 7.6$ containing $0.1 \%$ gelatin and assayed for P4, E2, and T concentrations using commercial RIA kits. Standard curves with the steroids dissolved in the same phosphate buffer were performed in every run. The limits of detection were $30 \mathrm{pg} / \mathrm{g}$ for T, $10 \mathrm{pg} / \mathrm{g}$ for E2, and $40 \mathrm{pg} / \mathrm{g}$ for P4. Intra-assay coefficients of variations were 14.8 
$\%(\mathrm{~T}), 12.1 \%(\mathrm{E} 2)$, and $6.5 \%(\mathrm{P} 4)$. Inter-assay coefficients of variations were $15 \%(\mathrm{~T}), 11.2 \%(\mathrm{E} 2)$, and $7.2 \%(\mathrm{P} 4)$.

\section{Expression profiles of target genes}

The expression of 27 genes was analyzed by quantitative RTPCR (qPCR) (Table 1). The basal expression levels of the genes were measured at individual level on whole soft bodies of 15 oysters per group (SWC, SC, D) taken at the end of the second diuron peak. These samples were individually frozen in liquid nitrogen and ground with a Mixer Mill MM 400 (Retsch) under liquid nitrogen conditions. Individual frozen oyster powders were stored at $-80{ }^{\circ} \mathrm{C}$ until use. Aliquots of $20 \mathrm{mg}$ oyster powders were homogenized in $1 \mathrm{ml}$ of Trizol ${ }^{\circledR}$ reagent (Invitrogen ${ }^{\circledR}$ ) for total RNA extraction according to the manufacturer's instruction. RNA samples were treated with DNase I (Invitrogen) to eliminate contaminating genomic DNA and precipitated with $3 \mathrm{M}$ sodium acetate. Total RNA amount and purity were checked by using NanoDrop ND-1000 spectrophotometer (Thermo Scientific, Les Ulis, France) and integrity was analyzed by $1.5 \%$ agarose gel electrophoresis. Fifty nanograms of individual total RNA samples were reversed-transcribed using M-MuLV Reverse Transcriptase according to the manufacturer's protocol (BioLabs®).

qPCR analyses were carried out in duplicate on the LightCycler 480 (Roche) in a final volume of 7.5 $\mu \mathrm{L}$ containing $4.2 \mu \mathrm{L}$ of reaction Syber Green Mix (Roche), $0.4 \mu \mathrm{L}$ of each primer $(0.6 \mu \mathrm{M}$ final concentration), and $2.5 \mu \mathrm{L}$ of individual cDNAs ( $2 \mathrm{ng}$ of equivalent RNAs). Pipetting steps were performed by the ECHO 525 acoustic liquid handler. Primer sequences used to amplify the 27 selected genes and the three reference genes are shown in Table 1. Cycling qPCR $25 \mathrm{~s}$. At the end of the program, a melting curve of PCR program consisted in a pre-incubation step at $90{ }^{\circ} \mathrm{C}$ for product was performed to ensure the production of a single $10 \mathrm{~min}$, followed by 40 cycles of denaturation at $90{ }^{\circ} \mathrm{C}$ for specific product. The relative expression was normalized ac10 s, annealing at $57^{\circ} \mathrm{C}$ for $20 \mathrm{~s}$, and extension at 72 ${ }^{\circ} \mathrm{C}$ for cording to the $\Delta \Delta \mathrm{Ct}$ method (Livak and Schmittgen 2001) with the Cq geometric mean value of the eukaryotic translation elongation factor 1-alpha (Cg-efl $\alpha$ : AB122066), the ribosomal protein L40 (Cg-rp140: FP004478), and the 40S ribosomal protein S6 (Cg-rps6: CU686508) as endogenous reference genes (Rosa et al. 2012).

\section{Time-course activity of enzymes involved in biotransformation and antioxidant defenses}

To assess the time-course activity of glutathion-S-transferase (EC 2.5.1.18), catalase (EC 1.11.1.6), and glutamine synthetase (EC 6.3.1.2), pieces of oyster digestive gland were individually sampled at T0 (24 individuals) and in each experimental group at the beginning and end of the two herbicide pulses (24 per group, 8 in each triplicate tank at Tfp1 and Tfp2). Samples were frozen and stored in liquid nitrogen up to analysis.

Samples were thawed in ice and homogenized in a phosphate buffer $\left(\mathrm{K}_{2} \mathrm{HPO}_{4} / \mathrm{KH}_{2} \mathrm{PO}_{4} 100 \mathrm{mM}, \mathrm{pH}\right.$ $7.4, w / v=1 / 3)$ and a Tris buffer saline $(50 \mathrm{mM}$ Tris- $\mathrm{HCl} \mathrm{pH} \mathrm{7.5,150} \mathrm{mM} \mathrm{NaCl})$ for CAT and GS, and GST, respectively. Homogenates were centrifuged for $15 \mathrm{~min}$ at $9000 \mathrm{~g}$ at $4{ }^{\circ} \mathrm{C}$ to recover the S9 fractions. The protein concentration of each sample was then measured by a colorimetric Bradford method using Bio-Rad protein assay reagent at $595 \mathrm{~nm}$. The selected activities were then measured in 96-well microplates using a Safire spectrofluorimeter (TECAN). 
CAT activity was measured as described by Greenwald (1985), using the decrease in absorbance at $240 \mathrm{~nm}$, due to $\mathrm{H}_{2} \mathrm{O}_{2}$ consumption. GST activity was measured using 1 chloro-2,4-dinitrobenzene (CDNB) as a substrate and the occurrence of GSH-CDNB complex was followed at $340 \mathrm{~nm}$ (Habig et al. 1974). GS activity was assayed by the $\gamma g$ glutamyl transferase reaction as described by Webb and Brown (1976) and modified by Saha et al. (2002). The formation of $\gamma$-glutamyl hydroxamate was followed at $543 \mathrm{~nm}$.

Specific activity was expressed in nanomole per minute per milligram $\left(\mathrm{nmol} \mathrm{min} \mathrm{mg}^{-1}\right.$ ) protein for CAT and GS and in micromole per minute per milligram $\left(\mu \mathrm{mol} \mathrm{min}^{-1} \mathrm{mg}^{-1}\right)$ for GST.

\section{Phagocytosis assay}

The phagocytic activity of hemolymph cells has been assessed in vitro according to a previously described method (Auffret et al. 2004) applied for the last decade to several bivalve species. Briefly, two $50 \mu \mathrm{L}$ replicate samples of freshly withdrawn hemolymph ( $n=12$ individuals per group at Tfp1 and Tfp2) were incubated in a 96-well microplate with inert, fluorescent particles (Polysciences, Fluoresbrite ${ }^{\mathrm{TM}}$ YG $2.0 \mu \mathrm{M}$ latex microspheres) at an estimated 1:30 ratio for $4 \mathrm{~h}$ at a standard temperature of $15^{\circ} \mathrm{C}$. The incubation medium was removed and the cell suspension fixed with a commercial paraformaldehyde solution (BD, CellFix ${ }^{\mathrm{TM}}$ ) until analysis by flow cytometry (GUAVA EasyCyte ${ }^{\mathrm{TM}}$ ). Parameters used to characterize the phagocytic activity were obtained through data analysis with the GUAVA ExpressPro ${ }^{\mathrm{TM}}$ software. For each individual, a phagocytic index (PI, expressed in \% positive cells) was calculated as the number of cells having engulfed three beads or more. The normalized phagocytic capacity of positive cells (NPC, expressed in arbitrary units), corresponding to the estimated number of particles internalized per active cell, was calculated from the same histogram of fluorescence intensity distribution (log units) as the geometric meanofthisselectedevent subpopulation. This parameter was normalized with the fluorescence value obtained for single beads as recommended by Lehmann et al. (2000).

\section{Statistics}

For gene expression, analyses were done with the $\mathrm{R}$ software (v3. 1 64bits) and ddCt package (v1.18.0). For non-normal values, Kruskal-Wallis test was used, followed by a MannWhitney pairwise comparison test. Significant differences were considered at $p<0.05$.

Enzymatic biomarker responses were analyzed using Statistica 8.0 (Statsoft, Inc.). Raw data were first tested for normality (Shapiro test) and homogeneity of variances (Levene test). For normal values, one-way or main effects ANOVAwere used followed by Tukey's pairwise comparison test if required. Results of quantitative histology were compared using a Student's test. Values were significantly different for $p<0.05$.

\section{RESULTS}

Diuron exposure at an environmentally realistic concentration did not affect gametogenesis course, sex ratio, reproductive effort, and total steroid levels 
Analysis of gonad histology showed that at the beginning of the experiment and so before the first herbicide pulse, most of the oysters already started gametogenesis (stage I or II) (Fig. 1). At the end of the broodstock conditioning, no difference in gametogenesis course was noticed between the control and diuron-exposed oysters. They were all globally mature, reaching stage III of gonad development (Fig. 1). Gametogenesis was synchronous in males and females (Fig. 1). In the control group, a slightly better use of storage tissue for gamete production has been achieved (Fig. 2). From a quantitative point of view, no effect of solvent or diuron was observed on the sex ratio, nearly 50/50 whatever the experimental groups. Although a significant decrease in genitor wet weight has been observed during this experiment following diuron exposure (Barranger et al. 2014), no quantitative difference was noticed between the three experimental groups in terms of total slide surface and gonad surface (data not shown). The three experimental groups present the same gonad index at the end of the broodstock conditioning (Fig. 3). A high inter-individual variability in the levels of estradiol, testosterone, and progesterone was observed in gonads, with no clear relationship with sex or gonad development stage (Fig. 4). Concerning the impact of diuron exposure, no effect on steroid levels was observed at Tfp2 in comparison with levels measured in control groups. However, an upward trend was noticed at the time of spawning (Tp) for $\mathrm{T}$ and $\mathrm{P} 4$ following herbicide exposure, resulting in a 5.5- and 4.5-fold increase in $\mathrm{T}$ and $\mathrm{P} 4$ levels, respectively. On the other hand, E2 was the only steroid whose level changed over the length of the experiment: a significant decrease in E2 was observed during maturation in both control and assay tanks.

\section{Diuron significantly affected the expression of genes involved in apoptosis, gene transcription and repair, replication and methylation of the DNA}

The effect of diuron exposures on the oysters has been analyzed at the transcriptional level. For that, we selected 27 genes according to their broad relevance to function categories that could be affected upon pesticide exposure, namely stress response, xenobiotic biodegradation, antioxidant defenses, and apoptosis (Table 1). Those categories were also DNA methylation, gene transcription regulation, DNA replication, recombination and DNA repair, and cytokinesis that have major functions particularly during gametogenesis (Dheilly et al. 2012).

Among the analyzed genes involved in stress response, xenobiotic degradation or antioxidant activities, no significant differences were seen between the three oyster groups in their expression levels (Fig. 5a-c, respectively). In apoptosis gene category (Fig. 5d), cytochrome c expression was increased in oysters exposed to diuron or to the solvent but significantly only in the case of the herbicide exposure $(p=0.007)$. Conversely, oyster exposure to diuron led to a decrease in the expression of caspase 3 that appeared to be significantly downregulated in oysters exposed to the solvent alone $(p=0.005)$.

Diuron and solvent exposures affected the expression levels of DNMT1 and DNM3A from DNA methylation function category (Fig. 5e), with significant decrease in DNMT1 expression in diuron oyster group ( $\mathrm{p}=0.008$ ). In gene transcription regulation category (Fig. $5 \mathrm{f}$ ), gene expression levels were reduced in diuron oyster group, and at a lesser extent in the solvent group, but only KDM1 was significantly affected by diuron exposure $(\mathrm{p}=0.02)$. In DNA repair and DNA replication category, diuron was shown to significantly increase the expression level of XRCC4 $(\mathrm{p}=0.03)$ whereas those of CAF1 was significantly decreased $(p=0.04$ ) (Fig. $5 \mathrm{~g}, \mathrm{~h}$ ). It is noteworthy that in all three oyster groups, great variability in gene expression was observed in TOP1 expression from zero to more than 400 -fold 
changes according to individuals (Fig. 5h). Finally, PRC1 involved in cytokinesis was observed overexpressed in exposed oysters, but only significantly upon diuron exposure $(p=0.02)$ (Fig. 5i).

\section{No change in the activity of enzymatic biomarkers was observed}

No effect of diuron or solvent exposure was shown in the activity of GST, GS, and CAT in oyster genitors $(p>0.05)$. CAT was the only enzyme whose level changed significantly with time but independently from diuron exposure $(p<0.001)$.

\section{Diuron exposure altered the phagocytic activity of oyster hemocytes}

The defense status of genitor oysters was assessed by measuring two major parameters describing the phagocytic activity of circulating hemocytes, namely the phagocytosis index, in the all hemolymph cell population and the phagocytic capacity of active hemocytes. At Tfp1, both parameters were found altered by diuron exposure but also by the solvent (Fig. 6). The percentage of active cells (phagocytosis index) dropped from 71.9 to 55.8 and $60.0 \%$, respectively $(p<0.001)$. Exposure to diuron had a stronger effect on the phagocytic capacity of hemocytes compared to both untreated and solvent-exposed $(p<0.001)$. At Tfp 2 , the mean phagocytic capacity was moderately increased $(p=0.11)$ for diuronexposed oysters (12.1 units) compared to the other treatments (9.7 and 8.4 units for the SWC and SC controls, respectively).

\section{DISCUSSION}

\section{Diuron affected the expression of genes belonging to functions known to play a major role during oyster gametogenesis and modulated the phagocytic activity of hemocytes}

The effects of pollutant exposure on reproduction are widely studied in ecotoxicology because the effects observed at individual level can bring information on the adverse effects encountered by the whole population at a longer time scale. Since the middle of the 1990s, there is a growing number of papers dedicated to the effect of pollution on animal reproduction. The effects of pollutant exposure on reproduction can be assessed in adults at different levels, from the molecular (modulation of the expression level of genes involved in sex determination, steroid synthesis and regulation,...) to biochemical (titration of sexual steroids, measurement of enzymes involved in steroid synthesis or homeostasis) or tissue levels (histological analysis of the gonad: sex ratio, reproductive effort, gametogenesis kinetics). The impact of pollutant exposure on both gamete viability and functionality, as well as on hatching rate and early developmental stages is also highly relevant to assess adverse effects on reproduction. In addition, the potential ofa substance to be an endocrine disruptor can be easily determined both in vitro and in vivo thanks to the use of specific assays (Clode 2006; Rotroff et al. 2013).

In this context, we have assessed the effect of a pulse exposure to the herbicide diuron on oyster reproduction. At tissue level, no significant effect of diuron on gametogenesis course and reproductive effort has been achieved. In several aquatic species, chemical pollution has already been shown to impair gametogenesis. In the oyster, Crassostrea angulata, from different locations in Taiwan, low gonad 
maturity index and pathological alterations (e.g., atresia, hemocytic infiltration of gonadal tissue) were associated to chemical pollution, in particular to the presence of elevated heavy metal concentrations (Vaschenko et al. 2013). Recently, in vitro exposure of zebra fish ovary tissue to the herbicide glyphosate (15 days, $65 \mathrm{mg} / \mathrm{L}$ ) resulted in a significant increase in both oocyte diameter and in the presence of unusual concentric membranes associated with the external membranes of mitochondria and yolk granules (Armiliato et al. 2014). In the present study, the absence of diuron effect on oyster gonad structure could be related to the low concentrations of diuron selected for the experiment as well as to the short duration of the exposure that was limited to only two 7 day-exposure pulses. Moreover, it cannot be excluded that differences may also exist between the different gametogenesis stages in terms of pollutant sensitivity. As a matter of fact, in this study, oyster genitors have been exposed to diuron after the major peak of gonial mitosis when they already started gametogenesis. Because the reproductive effort is highly dependent on the quality of gonial mitosis, it would have been at higher risk to expose the genitors sooner to target this active phase of gametogenesis. Moreover, it would have been interesting to follow up the expression of specific markers of germinal niche to assess the impact of diuron on both the early stages of gametogenesis and germ cell line. These marker genes such as vasaand piwi-like genes have been previously identified by sequence homology in the oyster but their function still remains to be clarified (Fabioux et al. 2004, 2009; Zhang et al. 2012).

Interestingly, results obtained at molecular level highlighted an impact of diuron exposure on the expression of genes belonging to functions known to play a major role during oyster gametogenesis such as DNA methylation, gene transcription regulation, DNA replication, recombination and DNA repair, and cytokinesis (Dheilly et al. 2012). As a matter of fact, gametogenesis is characterized by a high mitotic activity. As a consequence, cell division and differentiation request mechanisms involved in both gene regulation including epigenetic mechanisms, gene transcription, and DNA replication. In our study, diuron decreased the expression level of DNMT1, KDM1, and CAF1 that are respectively involved in DNA methylation maintenance, gene transcription regulation, and DNA replication. To the opposite, it significantly increased the expression of cytochrome c, XRCC4, and PRC1 genes. Modulation of these latter genes involved in apoptosis, DNA repair, and cytokinesis could indicate a need for maintaining the genome integrity of the cells. Cytochrome $\mathrm{c}$ initiates a major caspase activation pathway in response to apoptotic stimuli that can lead to subsequent cell death. Apoptotic cells are known to present a high level of DNA damage that could be repaired in some extent by DNA repair mechanisms. Moreover, the presence of DNA lesions can activate checkpoint pathways that regulate specific DNA repair mechanisms all along the different cell cycle phases, modifying cytokinesis. It is worth mentioning that this assumption is in accordance with the results previously obtained by Barranger et al. (2014) on the genotoxicity of diuron in oyster genitors from the present experiment. They demonstrated the genotoxicity of the herbicide by the detection of structural DNA lesions in both germinal (8-oxodGuo) and gamete (DNA strand breaks) genitor cells, respectively (Barranger et al. submitted; 2014). Moreover, they put forward a decreased in the hatching rate and a higher level of developmental abnormalities when using embryo from diuron-exposed genitors for fecundation (Barranger et al. 2014). Taking into account these latter results, we can so affirm that despite the absence of structural changes in gonad tissue, diuron exposure had a negative effect on gamete quality in terms of DNA integrity and on progeny early performances.

Finally, in our study, an upward trend for testosterone and progesterone levels at time of spawning was observed in diuron-exposed genitors but it was not statistically significant. Because there are 
significant evolutionary divergences in endocrine strategies, it remains difficult to transpose knowledge acquired in higher vertebrates to invertebrates. Testosterone, progesterone and estradiol were unequivocally identified in mussels (Reis-Henriques et al. 1990), but it is still difficult to conclude that these steroids function as in invertebrates (Scott 2013). In fish, estrogens play a role in the regulation of gonadal sex differentiation and sex change in most teleost fishes (Nakamura et al. 2003; Guiguen et al. 2010). In the present study, a significant decrease of E2 content in gonads was observedovermaturation, which agreeswith the steroidogenic shift from E2 to progestagens, occurring in fish ovarian follicles immediately prior to oocyte maturation, which is needed for the growing oocytes to enter the maturation stage. Such as in fish, progesterone could be involved in oyster oocyte maturation and germinal vesicle breakdown (Dimastrogiovanni et al. 2015).

In addition to the molecular effect of diuron on gametogenesis, herbicide exposure was shown to reduce the phagocytic capacity of hemolymph cells, a parameter linked to hemocyte competence, after the first exposure pulse when the number of active cells remained slightly altered. Herbicides appear as substances able to modulate the immune status of aquatic invertebrate species, at environmental levels within few days in adult oysters (Gagnaire et al. 2007) or within hours in young individuals (LunaAcosta et al. 2012). These responses observed after the first exposure pulse could be considered as early effects of contamination. The exact mechanisms of action remain unknown and chronic exposure of Pacific oysters to diuron (Bouilly et al. 2007) did not show any dose-effect relationship, indicating possible indirect consequence of other physiopathological, systemic alterations. Stress-induced immunomodulation has been reported in several groups of mollusk species as abalones (Hooper et al. 2007) and oysters (Lacoste et al. 2001). As so-called effect biomarkers, immunotoxic responses are not necessarily induced directly by contaminants but would correspond to some secondary stress response. In the present study, we hypothesize that a «general stress » state was induced upon the first exposure pulse. Observation in these oysters of genotoxic effects (most probably linked to oxidative stress induction) supports this hypothesis (Barranger et al. 2014). Other molecular biomarkers reported after the secondexposurepulse with a higher targeted concentration of pesticides, rather reveal interactions with biological targets in tissues.

\section{Fate of diuron in oyster and detoxification process}

The effects of diuron we observe here in oyster genitors at both molecular (gene expression) and cellular (cell immunity) levels complete those results previously obtained by Barranger et al. (2014; submitted) on either genitors (genotoxicity and reduced growth) and their descent (genomic abnormalities, reduced hatching rate and growth, developmental abnormalities). All these effects are thought to be highly dependent from diuron's fate once absorbed in the oyster.

The bioconcentration factor of diuron in oyster was 7 in the study of Buisson et al. (2008) up to 17 in the study of LunaAcosta et al. (2012). These values remained low, indicating a weak ability of diuron to bioaccumulate in oyster tissues. Diuron is hence probably biotransformed into its main metabolites, namely $N$-(3,4-dichlorophenyl)- $N$-methylurea (DCPMU) and 3,4-dichlorophenylurea (DCPU), such as in other organisms like bacteria (Vercraene-Eairmal et al. 2010), rat, dog, and human (Abass et al. 2007). None of these metabolites have been yet detected in the oyster but HPLC MS-MS analysis actually in progress in our laboratory exhibited the ability of oyster to produce both metabolites in vitro (unpublished results). It is worth mentioning that in C. gigas exposed to a mixture of pesticides containing glyphosate, its main metabolite named aminomethylphosphonic acid (AMPA) was detected 
in oyster tissues, probably resulting from the biotransformation of the parent herbicide in the oyster (Geret et al. 2013). Moreover, the biotransformation products of other pollutants such as the PAHs, benzo(a)pyrene (Anderson 1985) and pyrene (Bustamante et al. 2012) or the pesticides, chlorpyrifos (Woodburn et al. 2003), and pentachlorophenol (Shofer and Tjeerdema 1993) have already been identified in the oyster Crassostrea virginica demonstrating the metabolic ability of Crassostrea species to biotransform xenobiotics.

Biotransformation relies on different kinds of enzymes involved in oxidation, reduction, and hydrolyse (phase I enzymes) and conjugation with endogenous molecules to increase hydrophilicity (phase II enzymes). Cytochrome P450 and GST are phases I and II enzymes, the more frequently measured to assess pollutant exposure explaining their selection for the transcriptional analysis. In the present paper, the expression levels of these two genes were shown to be nonmodulated by diuron exposure. Because biotransformation is a rapid response to pollutant absorption, sampling may have occurred too late (end of the second herbicide pulse) to detect change in gene expression related to xenobiotic biotransformation. The short exposure pulse at an environmentally concentration can also explain the absence of significant change in gene expression level. Few data are available on the transcriptional analysis of biotransformation genes in the oyster. These last years saw a significant advance in oyster genomic resources (Zhang et al. 2012). A gene belonging to the CYP sub-family, CYP356A1, was identified in oysters exposed to a sanitary sewage-effluent (Rodrigues-Silva et al. 2015). Through the production of a CYP356A1 purified protein and a corresponding mouse polyclonal antibody, dot blot analysis highlighted the inducibility of the CYP proteins in the lining epithelial cells of mantle, stomach, intestine, and gills but also in free cells such as hemocytes. In the species Crassostrea brasilia, recent work also indicated the presence of new cytochrome P450 and glutathioneS-transferase genes those expression was upregulated by exposure to phenantrene (Lüchmann et al. 2014). Other genes involved in xenobiotic detoxification process such as those coding the multixenobiotic resistance protein P-170 were also identified in Crassostrea species (Zhang et al. 2012; Mottier et al. 2014). These new data will help to better investigate the response of biotransformation genes in the case of pollutant exposure. It is worth mentioning that antioxidant genes such as catalase and superoxide dismutase were also not modulated by diuron exposure. Numerous pollutants including herbicides are known to induce an oxidative stress in the oyster, involving antioxidant defenses. Diuron is thought to induce toxicity in oyster by oxidative stress as suggested by the oxidative DNA damage it induces in the oyster (Akcha et al. 2012; Barranger et al. 2014).

At biochemical level, no effect of diuron exposure was detected on CAT, GST, and GS activities. In the study from Geret et al. (2013), the modulation of these activities was reported in C. gigas following exposure to pesticides. However, oysters were subjected to a continuous exposure to a mixture of pesticides $\left(0.8 \mu \mathrm{gL}^{-1}\right.$ alachlor, $0.6 \mu \mathrm{g} \mathrm{L} \mathrm{L}^{-1}$ metolachlor, $0.7 \mu \mathrm{gL}^{-1}$ atrazine, $0.6 \mu \mathrm{gL}^{-1}$ terbuthylazine, 0.5 $\mu \mathrm{gL}^{-1}$ diuron, $0.6 \mu \mathrm{gL}^{-1}$ fosetyl aluminum, $0.05 \mu \mathrm{gL}^{-1}$ carbaryl, and $0.7 \mu \mathrm{gL}^{-1}$ glyphosate) and at a concentration higher $\left(4.55 \mu \mathrm{gL}^{-1}\right)$ than those tested in the present study $\left(0.2-0.3 \mu \mathrm{gL}^{-1}\right)$. For the latter exposure conditions, a significant increase in gill and digestive gland CAT and GS activity was observed. GST was also significantly increased but only in the digestive gland. It is noteworthy that changes in enzymatic activity levels were observed rapidly after the beginning of the experiment. In the case of CAT activity, increase was significant at day 1 and 3 but no longer at day 7. Such as mentioned earlier for the expression of genes involved in biotransformation and antioxidant defenses, the absence of effect could be related to late sampling but also to the short exposure period and weak tested concentration. 


\section{CONCLUSION}

Short pulse exposure of oyster genitors to diuron during gametogenesis was performed in this study at a concentration realistic in an environmentally point of view. Whereas no significant direct effect of herbicide exposure was observed on oyster steroid levels, gametogenesis course, and reproductive effort, diuron affected the expression of genes belonging to functions known to play a major role during oyster gametogenesis. These functions are DNA methylation, gene transcription regulation, DNA replication, recombination and DNA repair, and cytokinesis. Interestingly, these molecular responses may reflect diuron genotoxicity responsible for the decreased in gamete and progeny quality we reported in diuronexposed genitors from the same experiment. Short exposure to diuron at an environmental concentration impacted the oyster genitors themselves but also their next generation when exposed at sensitive physiological state such as gametogenesis. Further experiments should explore the mechanisms by which diuron exerts its toxic effect on ongoing gametogenesis. These results address the question of the transgenerational effect of herbicides on germ lineage, fitness, and adaptive capacity of oyster populations in anthropic environment.

\section{ACKNOWLEDGMENTS}

This work was funded by the French National Research Agency (ANR-CESA-01601) and the French Research Institute for Sea Exploration. The authors are grateful to Béatrice Adeline (histological approaches) for her punctual technical assistance.

\section{REFERENCES}

Abass K, Reponen P, Turpeinen M, Jalonen J, Pelkonen O (2007) Characterization of diuron Ndemethylation by mammalian hepatic microsomes and cDNA-expressed human cytochrome P450 enzymes. Drug Metab Dispos 35:1634-1641

Akcha F, Spagnol C, Rouxel J (2012) Genotoxicity of diuron and glyphosate in oyster spermatozoa and embryos. Aquat Toxicol 106-107: 104-113

Anderson RS (1985) Metabolism of a model environmental carcinogen by bivalve molluscs. Mar Environ Res 17:137-140

Armiliato N, Ammar D, Nezzi L, Straliotto M, Muller YM, Nazari EM (2014) Changes in ultrastructure and expression of steroidogenic factor-1 in ovaries of zebrafish Danio rerio exposed to glyphosate. J Toxicol Environ Health A 77:405-414

Auffret M, Duchemin M, Rousseau S, Boutet I, Tanguy A, Moraga D, Marhic A (2004) Monitoring of immunotoxic responses in oysters reared in areas contaminated by the BErika ${ }^{\wedge}$ oil spill. Aquat Living Res 17:297-302

Barranger A, Heude-Berthelin C, Rouxel J, Adeline B, Benabdelmouna A, Burgeot T, Akcha F (submitted) Parental exposure to the herbicide diuron resulted in oxidative DNA damage in germinal cells of the Pacific oyster, Crassostrea gigas. Comp Biochem Physiol

Barranger A, Akcha F, Rouxel J, Brizard R, Maurouard E, Pallud M, Menard D, Tapie N, Budzinski $\mathrm{H}$, Burgeot T, Benabdelmouna A (2014) Study of genetic damage in the Japanese oyster induced by an 
environmentally-relevant exposure todiuron: evidence of vertical transmission of DNA damage. Aquat Toxicol 146:93-104

Barranger A, Benabdelmouna A, Dégremont L, Burgeot T, Akcha F (2015) Parental exposure to environmental concentrations of diuron leadstoaneuploidy inembryos of thePacific oyster, asevidenced by fluorescent in situ hybridization. Aquat Toxicol 159:36-43

Berthelin C, Kellner K, Mathieu M (2000) Histological characterization and glucose incorporation into glycogen of the Pacific oyster Crassostrea gigas storage cells. Mar Biotechnol 2:136-145

Bouilly K, Bonnard M, Gagnaire B, Renault T, Lapègue S (2007) Impact of diuron on aneuploidy and hemocyte parameters in Pacific oyster Crassostrea gigas. Arch Environ Contam Toxicol 52:58-63

Buisson S, Bouchart V, Guerlet E, Malas JP, Costil K (2008) Level of contamination and impact of pesticides in cupped oyster, Crassostrea gigas, reared in a shellfish production area in Normandy (France). J Environ Sci Health Part B 43:655-664

Burgeot T, Gagnaire B, Renault T, Haure J, Moraga D, David E, Boutet I, Sauriau PG, Malet N, Bouchet V, Le Roux A, Lapègue S, Bouilly K, Le Moullac G, Arzul G., Knoery J., Quiniou F, Barcher C, Soletchnick P (2008) Oyster summer morality risks associated with environmental stress. In: Samain, J.F., McCom-Bie, H. (Eds.) Summer Mortality of Pacific Oyster Crassostrea Gigas. The Morest Project. Éd. Ifremer/Quæ pp 107-151

Bustamante P, Luna-Acosta A, Clemens S, Cassi R, Thomas-Guyon H, Warnau M (2012) Bioaccumulation and metabolisation of (14)Cpyrene by thePacificoysterCrassostreagigas exposed via seawater. Chemosphere 87:938-944

Caquet T, Roucaute M, Mazzella N, Delmas F, Madigou C, Farcy E, Burgeot T, Allenou JP, Gabellec R (2013) Risk assessment of herbicides and booster biocides along estuarine continuums in the Bay of Vilaine area (Brittany France). Environ Sci Pollut Res 20:651- 666

Clode SA (2006) Assessment of in vivo assays for endocrine disruption. Best Pract Res Clin Endocrinol Metab 20:35-43

Dheilly N, Lelong C, Huvet A, Kellner K, Dubos MP, Rivière G, Boudry P, Favrel P (2012) Gametogenesis in the Pacific oyster Crassostrea gigas. A microarrays-based analysis identifies sex and stage specific genes. PLoS ONE 7:e36353

Dimastrogiovanni G, Fernandes D, Bonastre M, Porte C (2015) Progesterone is actively metabolized to $5 \alpha$-pregnane-3,20-dione and $3 \beta$-hydroxy-5 $\alpha$-pregnan-20-one by the marine mussel Mytilus galloprovincialis. Aquat Toxicol 165:93-100

Fabioux C, Pouvreau S, Le Roux F, Huvet A (2004) The oyster vasa-like gene: a specific marker of the germline in Crassostrea gigas. Biochem Biophys Res Commun 315(4):897-904

Fabioux C, Corporeau C, Quillien V, Favrel P, Huvet A (2009) In vivo RNA interference in oystervasa silencing inhibits germ cell development. FEBS 276(9):2566-2573

Gabe M (1968) Techniques histologiques. Masson et Cie Paris pp 11-13

Gagnaire B, Thomas-Guyon H, Burgeot T, Renault T (2006) Pollutant effects on Pacific oyster Crassostrea gigas (Thunberg), hemocytes: screening of 23 molecules using flow cytometry. Cell Biol Toxicol 22:1-14

Gagnaire B, Gay M, Huvet A, Daniel JY, Saulnier D, Renault T (2007) Combination of a pesticide exposure and a bacterial challenge: in vivo effects on immune response of Pacific oyster Crassostrea gigas (Thunberg). Aquat Toxicol 84:92-102 
Geret F, Burgeot T, Haure J, Gagnaire B, Renault T, Communal PY, Samain JF (2013) Effects of low-dose exposure to pesticide mixture on physiological responses of the Pacific oyster, Crassostrea gigas. Environ Toxicol 28:689-699

Greenwald RA (1985) Handbook of methods for oxygenradical research. CRC Press, Boca Raton

Guiguen Y, Fostier A, Piferrer F, Chang CF (2010) Ovarian aromatase and estrogens: a pivotal role for gonadal sex differentiation and sex change in fish. Gen Comp Endocrinol 165:352-366

Habig WH, Pabst MJ, Jakobi WB (1974) Glutathione S-transferase: the first enzymatic step in mercapturic acid formation. J Biol Chem 249: 7130-7139

Harvell CD, Kim K, Burkholder JM, Colwell RR et al (1999) Emerging marine diseases-climate links and anthropogenic factors. Science 285:1505-1510

Heude Berthelin C, Laisney J, Espinosa J, Martin O, Hernandez G, Mathieu M, Kellner K (2001) Storage and reproductive strategy in Crassostrea gigas from two different growing areas (Normandy and the Atlantic coast, France). Invertebr Reprod Dev 40:79-86

Hooper C, Day R, Slocombe R, Handlinger J, Benkendorff K (2007) Stress and immune responses in abalone: limitations in current knowledge and investigative methods based on other models. Fish Shellfish Immunol 22:363-379

Lacoste A, Malham SK, Cueff A, Poulet SA (2001) Noradrenaline modulates oyster hemocyte phagocytosis via a beta-adrenergic receptorcAMP signaling pathway. Gen Comp Endocrinol 122:252259

Lehmann AK, Sornes S, Halstensen A (2000) Phagocytosis: measurement by flow cytometry. J Immunol Methods 243:229-242

Livak KJ, Schmittgen TD (2001) Analysis of relative gene expression data using real-time quantitative PCR and the $2^{-\Delta \Delta C} \mathrm{~T}$ method. Methods 25:402-408

Lüchmann KH, Dafre AL, Trevisan R, Craft JA, Meng X, Mattos JJ, Zacchi FL, Dorrington TS, Schroeder DC, Bainy AC (2014) A light in the darkness: new biotransformation genes, antioxidant parameters and tissue-specific responses in oysters exposed to phenanthrene. Aquat Toxicol 152:324 334

Luna-Acosta A, Renault T, Thomas-Guyon H, Faury N, Saulnier D, Budzinski H, Le Menach K, Pardon P, Fruitier-Arnaudin I, Bustamante P (2012) Detection of early effects of a single herbicide (diuron) and a mix of herbicides and pharmaceuticals (diuron, isoproturon, ibuprofen) on immunological parameters of Pacific oyster (Crassostrea gigas) spat. Chemosphere 87:1335-1340

Mai H, Morin B, Budzinski H, Cachot J (2013) Environmental concentrations of irgarol, diuron and S-metolachlor induce deleterious effects on gametes and embryos of the Pacific oyster, Crassostrea gigas. Mar Environ Res 89:1-8

Mottier A, Séguin A, Devos A, Le Pabic C, Voiseux C, Lebel JM, Serpentini A, Fievet B, Costil K (2014) Effects of subchronic exposure to glyphosate in juvenile oysters (Crassostrea gigas): from molecular to individual levels. Mar Pollut Bull 95:665-677

Munaron D (2004) Étude des apports en herbicides et en nutriments par la Charente:modélisation de la dispersion de l'atrazine dans le bassin de Marennes-Oléron. In: Thèse de Doctorat Université Paris 6 Pierre et Marie Curie

Munaron D, Tapie N, Budzinski H, Andral B, Gonzalez JL (2012) Pharmaceuticals, alkylphenols and pesticides in Mediterranean coastal waters: results from a pilot survey using passive samplers. Estuar Coast Shelf Sci 114:82-92 
Nakamura M, Bhandari RK, Higa M (2003) The role estrogens play in sex differentiation and sex changes of fish. Fish Physiol Biochem 28:113-117

Petton B, Pernet F, Robert R, Boudry P (2013) Temperature influence on pathogen transmission and subsequent mortalities in juvenile Pacific oysters Crassostrea gigas. Aquac Environ Interact 3:257-273

Reis-Henriques MA, Le Guellec D, Remy-Martin JP, Adessi GL (1990) Studies of endogenous steroids from the marine mollusc Mytilus edulis L. by gas chromatography and mass spectrometry. Comp Biochem Physiol B95:303-309

Rodrigues-Silva C, Flores-Nunes F, Vernal JI, Cargnin-Ferreira E, Bainy AC (2015) Expression and immunohistochemical localization of the cytochrome P450 isoform 356A1 (CYP356A1) in oyster

Crassostrea gigas. Aquat Toxicol 159:267-275

Rosa R, de Lorgeril J, Tailliez P, Bruno R, Piquemal D, Bachere E (2012) A hemocyte gene expression signature correlated with predictive capacity of oysters to survive Vibrio infections. BMC Genomics 13:252

Rotroff DM, Dix DJ, Houck KA, Knudsen TB, Martin MT, McLaurin KW, Reif DM, Crofton KM, Singh AV, Xia M, Huang R, Judson RS (2013) Using in vitro high throughput screening assays to identify potential endocrine-disrupting chemicals. Environ Health Perspect 121:7-14

Royer J, Seguineau C, Park K, Pouvreau S, Choi KS, Costil K (2008) Gametogenetic cycle and reproductive effort assessed by two methods in 3 age classes of Pacific oysters, Crassostrea gigas, reared in Normandy. Aquaculture 277:313-320

Saha N, Dutta S, Bhattacharjee A (2002) Role of amino acid metabolism in air-breathing catfish, Clarias batrachus, in response to exposure to a high concentration of exogenous ammonia. Comp Biochem Physiol B133:235-250

Samain JF, Dégremont L, Soletchnik P, Haure J, Bédier E, Ropert M, Moal J, Huvet A, Bacca A, Van Wormhoudt A, Delaporte M, Costil K, Pouvreau S, Lambert C, Boulo V, Soudant P, Nicolas J, Le Roux F, Renault T, Gagnaire B, Geret F, Boutet I, Burgeot T, Boudry P (2007) Genetically based resistance to summer mortality in the Pacific oyster (Crassostrea gigas) and its relationship with physiological, immunological characteristics and infection processes. Aquaculture 268:227-243

Schmitt P, Duperthuy M, Montagnani C, Bachère E, DestoumieuxGarzón D (2012) Immune responses in the Pacific oyster Crassostrea gigas, an overview with focus on summer mortalities. In: Qin J (ed) Oysters physiology, ecological distribution and mortality. Nova Science Publishers Inc., New York

Scott AP (2013) Do mollusks use vertebrate sex steroids as reproductive hormones? II. Critical review of the evidence that steroids have

biological effects. Steroids 78:268-281

Shofer SL, Tjeerdema RS (1993) Comparative disposition and biotransformation of pentachlorophenol in the oyster (Crassostrea gigas) and abalone (Haliotis fulgens). Pest Biochem Physiol 46:85-95

Soletchnik P, Lambert C, Costil K (2005) Summer mortality of Crassostrea gigas (Thunberg) in relation to environmental rearing conditions. J Shellfish Res 24:197-207

Thomas KV, McHugh M, Waldock M (2002) Antifouling paint booster biocides in UKcoastal waters: inputs,occurrence andenvironmental fate. Sci Total Environ 293:117-127

Vaschenko MA, Hsieh HL, Radashevsky VI (2013) Gonadal state of the oyster Crassostrea angulata cultivated in Taiwan. J Shell Res 32: 471-482 
Vercraene-Eairmal M, Lauga B, Saint Laurent S, Mazzella N, Boutry S, Simon M, Karama S, Delmas F, Duran R (2010) Diuron biotransformation and its effects on biofilm bacterial community structure. Chemosphere 81:837-843

Webb JT, Brown GW Jr (1976) Some properties and occurrence of glutamine synthetase in fish. Comp Biochem Physiol 54B:171-175

Woodburn KB, Hansen SC, Roth GA, Strauss K (2003) The bioconcentration and metabolism of chlorpyrifos by the eastern oyster, Crassostrea virginica. Environ Toxicol Chem 22:276-284

Zhang G, Fang X, Guo X, Li L, Luo R, Xu F, Yang P, Zhang L, Wang X, Qi H, Xiong Z, Que H, Xie Y, Holland PW, Paps J, Zhu Y, Wu F, Chen Y, Wang J, Peng C, Meng J, Yang L, Liu J, Wen B, Zhang N, Huang Z, Zhu Q, Feng Y, Mount A, Hedgecock D, Xu Z, Liu Y, Domazet-Lošo T, Du Y, Sun X, Zhang S, Liu B, Cheng P, Jiang X, Li J, Fan D, Wang W, Fu W, Wang T, Wang B, Zhang J, Peng Z, Li Y, Li N, Wang J, Chen M, He Y, Tan F, Song X, Zheng Q, Huang R, Yang H, Du X, Chen L, Yang M, Gaffney PM, Wang S, Luo L, She Z, MingY, Huang W, ZhangS, Huang B, ZhangY, Qu T, Ni P, Miao G, Wang J, Wang Q, Steinberg CE, Wang H, Li N, Qian L, Zhang G, Li Y, Yang H, Liu X, Wang J, Yin Y, Wang J (2012) The oyster genome reveals stress adaptation and complexity of shell formation. Nature 490:49-54 


\section{TABLES \& FIGURES}

\section{Table 1}

List of the 27 genes analyzed by quantitative RT-PCR in oyster genitors and their respective primer sequences

\begin{tabular}{|c|c|c|c|c|}
\hline Gene name and function & Symbol & GenBank & Forward primer $\left(5^{\prime}-\right.$ & Reverse primer $\left(5^{\prime}-\right.$ \\
\hline \multicolumn{5}{|l|}{ Stress response } \\
\hline Heat shock protein & HSP74 & AAD31042 & GCATGTGAGCGAGCAAAACG & TGGCAGCTTGAACAGCAGC \\
\hline Complement $\mathrm{Clq}$-like protein & CIQL.3 & EKC 35623 & GCCAGGAAATCTGAAGAGTG & GTTATCCGACTCAAACAGTG \\
\hline Universal stress & USP & EKC39971 & TTGAGGTTTCCGTGAACGAG & AACAATCACCGGAACTGACG \\
\hline Cytochrome P450-related & CYP & EF451959 & AACATCATCGGAATGCT & GATACAGACCGCCGTAA \\
\hline Glutathione S-transferase & GST & EKC30389 & ATGACCTTCCTGAACACTGG & GTTGACCACAAAGGCCACTC \\
\hline \multicolumn{5}{|l|}{ Antioxidant } \\
\hline Peroxiredoxin & PRDX4 & ADC35419 & GATCACCATGAATGACCTCC & ACATTGGGACGGATTGTGTC \\
\hline Probable maleylacetoacetate isomerase & MAAI & ACO15091 & GCAGAATGGGCTAAGTTCTG & AGAGTCTAGCTGCTGAACAC \\
\hline $\begin{array}{l}\text { Mitogen-activated protein kinase } \\
\text { kinase kinase }\end{array}$ & M3K7 & EKC20090 & CGGAGGAGTTCAAACAACTG & TCGAGTAACGTAGTCGTTGG \\
\hline Cytochrome c & CYC & EKC38518 & GAGGACATCTGATTGCTTGC & TGTTACGGCAAGTCAACTGC \\
\hline Caspase- -3 & CASP3 & EKC30354 & ATCACCAGGAAGGATCATGG & GTTCATCCGAACACGACTCG \\
\hline \multicolumn{5}{|l|}{ DNA methylation } \\
\hline DNA (cytosine-5)-methyltransferase 1 & DNMT1 & EKC23761 & CCGGAGGATACACACAA & AGTACTCCTCTAGGCTT \\
\hline DNA methyltransferase 1-associated & DMAP1 & EKC 31208 & GTAGTAGCAAAGTCAGACC & TATACAGGGATGTCTACCG \\
\hline DNA (cytosine-5)-methyltransferase & DNM3A & EKC24789 & TATAGTCAACCCAGCTAGAAG & TGATAGTGTCTCTGATGTCG \\
\hline \multicolumn{5}{|l|}{ Gene transcription regulation } \\
\hline \multicolumn{5}{|l|}{ DNA repair } \\
\hline DNA repair protein & $\mathrm{XRCC4}$ & EKC30529 & AGACAGACTATGACAGGAT & TCACCGTTTGCATAGTTAC \\
\hline \multicolumn{5}{|l|}{ DNA replication and repair } \\
\hline $\begin{array}{l}\text { Probable histone-binding protein } \\
\text { Cafl isoform }\end{array}$ & CAF1 & XP_003424838 & TGCTTCACATTACGACAGCG & TGTCTICGTGGCGATGATAC \\
\hline \multicolumn{5}{|l|}{ DNA replication and transcription } \\
\hline DNA topoisomerase & TOP1 & EKC21526 & GCAACGAGGAGGTAACAAGG & TATAATCCGCCTTCGCTGTC \\
\hline DNA replication licensing factor & MCM7 & Q6NX31 & GCCAGAAATAGCAAGGACACC & TGGGCAGGATTGAGAGAGTC \\
\hline \multicolumn{5}{|l|}{ Cytokinesis } \\
\hline Protein regulator of cytokinesis & $\mathrm{PRCl}$ & 043663 & GTGAGAGAAAGTGAAGAGAC & TAGGATGCCACACTGCTGTC \\
\hline \multicolumn{5}{|l|}{ Genes used for normalization } \\
\hline Elongation factor 1 & EF1 & EKC33063 & GAGCGTGAACGTGGTATCAC & ACAGCACAGTCAGCCTGTGA \\
\hline Ribosomal protein L40 & RPL40 & EKC19428.1 & AATCTTGCACCGTCATGCAG & AATCAATCTCTGCTGATCTGG \\
\hline $40 S$ ribosomal protein S6 & RPS6 & AFJ91756 & CAGAAGTGCCAGCTGACAGTC & AGAAGCAATCTCACACGGAC \\
\hline
\end{tabular}




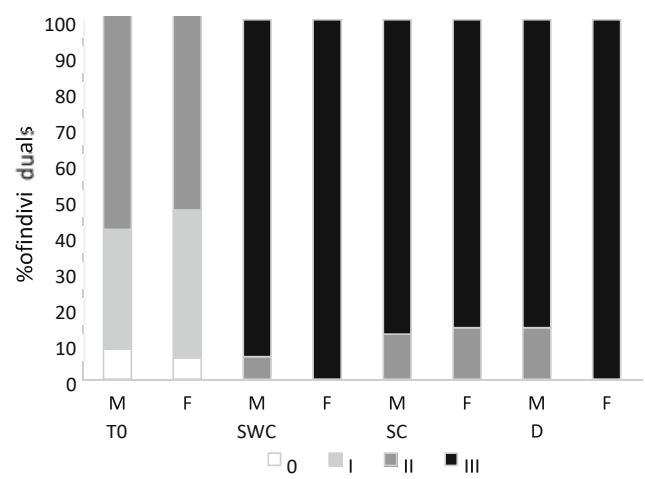

\section{Figure 1}

Gametogenesis course in the three experimental groups: sea water control (SWC), solvent control (SC), and diuron-exposed group $(D)$ and for both sexes (M and F). Results were expressed as percentage of oysters at each gametogenesis stage at the beginning of the experiment (T0) and at the end of the breeders conditioning. Stage 0: quiescent phase, stage I: first gonial mitosis, stage II: mitosis and meiosis, stage III: sexual maturity. $(n=30)$ 


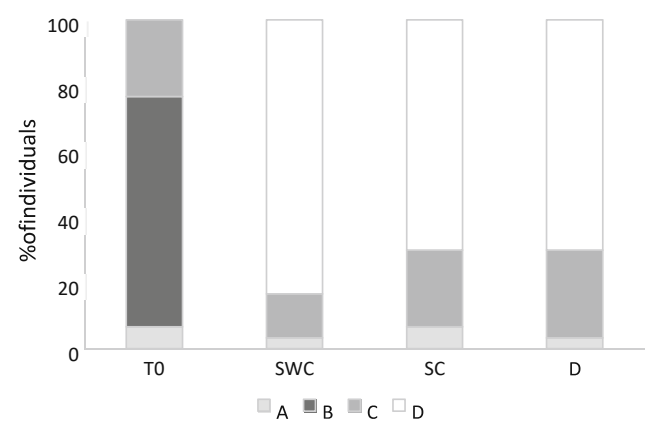

\section{Figure 2}

Storage tissue development in the three experimental groups: sea water control (SWC), solvent control (SC), and diuron-exposed group $(D)$. Results were expressed as percentage of oysters at each storage tissue stage at the beginning of the experiment (T0) and at the end of the breeders conditioning. Stage A: phase of restructuring, stage B: maximal storage tissue development, stage $\mathrm{C}$ : phase of regression, stage D: declined stage. $(n=30)$ 


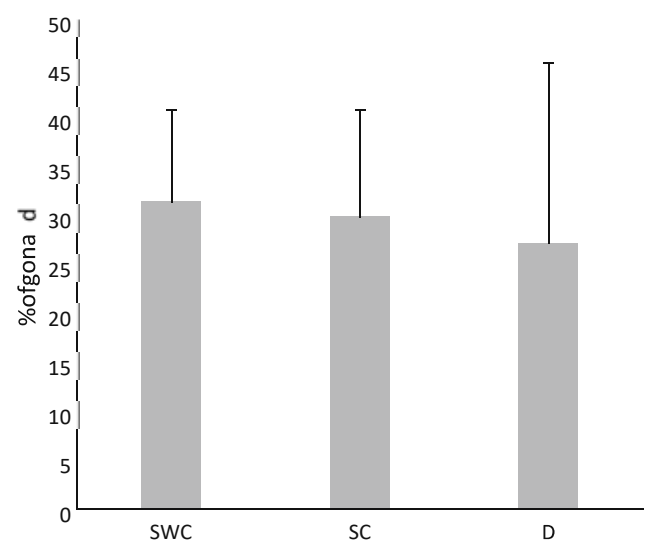

\section{Figure 3}

Assessment of oyster reproduction effort using stereological analysis of the relative percentage of gonad in the gonadal tissue area of the three experimental groups: sea water control (SWC), solvent control $(S C)$, and diuron exposed group $(D)$. Results were expressed as percentage of the whole surface animal occupied by gonad. $(n=15)$ 

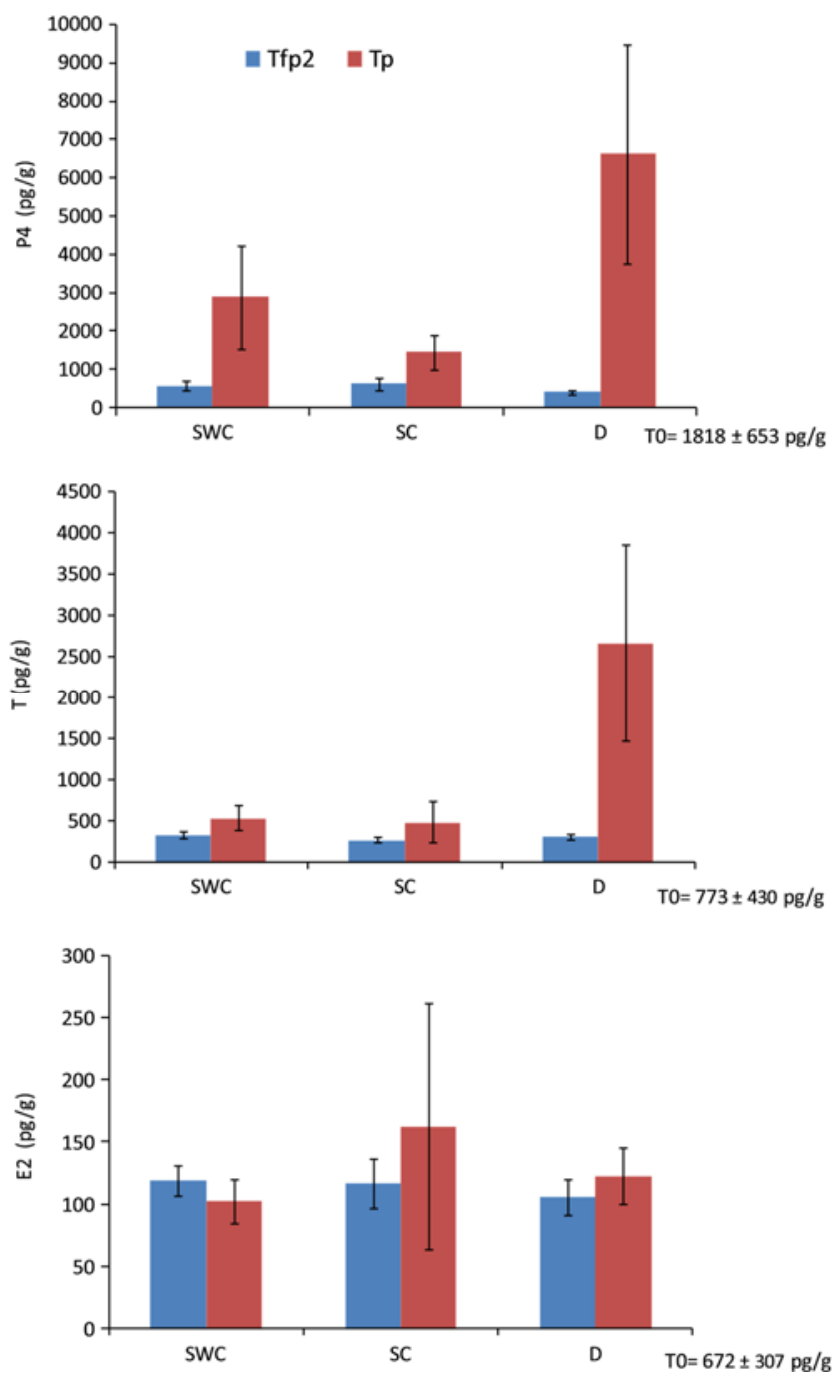

\section{Figure 4}

Levels of progesterone, testosterone, and estradiol in gonad tissue of control and diuronexposed oysters at Tfp2 and Tp. Concentrations determined in control oysters at time 0 are indicated in the bottom of the figures. SWC: control; SC: solvent control; D: diuron. Data expressed as mean \pm SEM $(n=6-9)$ 

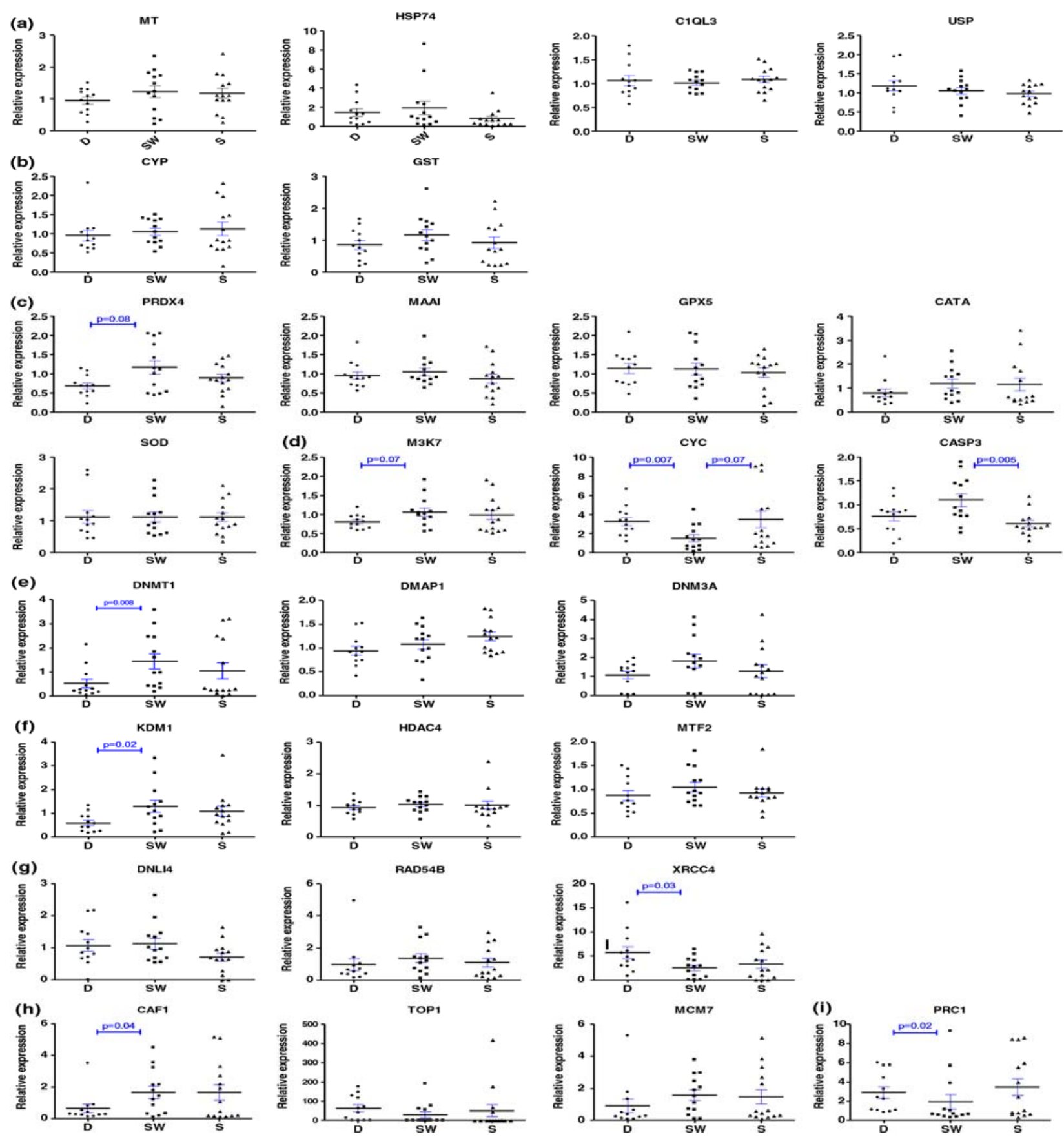

\section{Figure 5}

Expression levels of genes relevant to different functional categories in oyster genitors exposed respectively to Diuron $(D)$ in comparison with seawater $(S W)$ and solvent $(S)$ control groups. Selected genes belong to a stress response, $\mathbf{b}$ xenobiotic biodegradation, $\mathbf{c}$ antioxidant, $\mathbf{d}$ apoptosis, e DNA methylation, $\mathbf{f}$ gene transcription regulation, $\mathbf{g}$ DNA recombinaison and DNA repair, $\mathbf{h}$ DNA replication and repair, and $\mathbf{i}$ cytokinesis. Relative expression data were normalized with the $\mathrm{C}_{\mathrm{T}}$ geometric mean value of three reference genes (Cg-efl $\alpha, \mathrm{Cg}$-rp140, and Cg-rps6) according to the $2^{-\triangle \Delta C T}$ method. Significant differences in relative gene expressions between oyster groups $(\mathrm{D}, \mathrm{SW}$, and $\mathrm{S})$ were determined by Mann-Whitney $U$ tests and $p$ values are given if significant at the $p<0.05$ threshold 


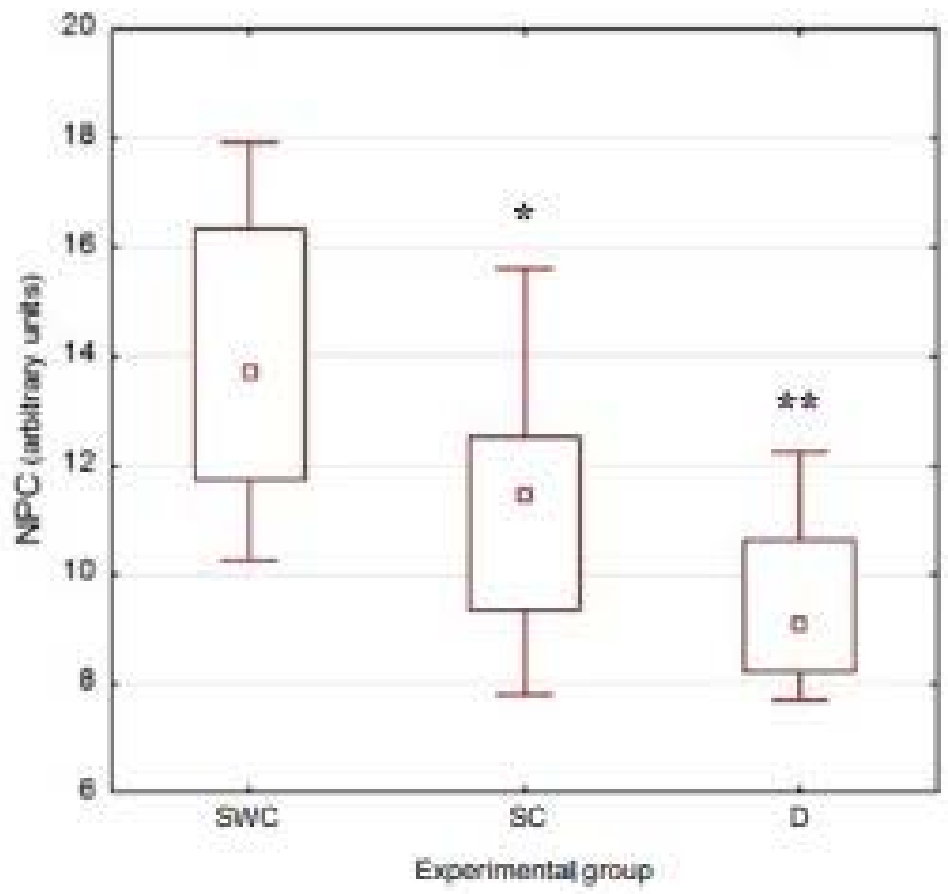

\section{Figure 6}

Normalized phagocytic capacity of hemocytes from genitor oysters measured in vitro at the end of the first exposure pulse. Plots display median value, first and third quartiles, and minimum and maximum of the data set. Significant at $* p<0.05$ and $* * p<0.001$ (Kruskal-Wallis) 